\title{
The efficacy of subcutaneous local analgesic infusion in the early postoperative period after bilateral total knee arthroplasty
}

\author{
İki taraflı total diz artroplastisi sonrası erken dönemde cilt altı \\ lokal analjezik infüzyonunun etkinliği
}

\author{
Mehmet Eroğlu, MD., ${ }^{1}$ Mehmet Serhan Er, MD., ${ }^{2}$ Levent Altınel, MD., ${ }^{2}$ \\ Serdar Kokulu, MD., ${ }^{3}$ Mehmet Yücehan, MD., ${ }^{1}$ \\ 'Department of Orthopedics and Traumatology, Medical Faculty of Afyon Kocatepe University, Afyonkarahisar, Turkey \\ ${ }^{2}$ Department of Orthopedics and Traumatology, Medical Faculty of Akdeniz University, Antalya, Turkey \\ ${ }^{3}$ Department of Anesthesiology and Reanimation, Medical Faculty of Afyon Kocatepe University, Afyonkarahisar, Turkey
}

\begin{abstract}
Objectives: This study aims to evaluate the analgesic and functional efficacy of subcutaneous local analgesic infusion (ScLAI) in the early postoperative period (especially on the second postoperative day) in patients undergoing simultaneous bilateral total knee arthroplasty with an intraoperative periarticular injection (PAI) of local analgesic cocktail.

Patients and methods: Fifteen patients (1 male, 14 females; mean age 62 years; range 52 to 76 years) who underwent simultaneous bilateral total knee arthroplasty ( 30 knees) and who received the same pre- and intraoperative analgesic protocols were included in this randomized, double-blind, placebo-controlled study. By using a flexible catheter, bupivacaine was administered for ScLAI to either knee (ScLAI group) and placebo infusion was applied to the other one (control group). Postoperative visual analog scale (VAS) pain scores and knee functions were compared between bupivacain and placebo infused knees.
\end{abstract}

Results: In the ScLAI group, VAS pain scores were lower than the control group during knee flexion and straight leg raise activities (SLR) on the second postoperative day. ScLAI also prevented the rebound pain following intraoperative PAI of local analgesic cocktail and prolonged the analgesic efficacy period of the cocktail during both knee flexion and SLR.

Conclusion: Subcutaneous infusion of bupivacaine in patients undergoing simultaneous bilateral total knee arthroplasty may prevent emergence of the rebound pain arising after application of intraoperative PAI of local analgesic cocktail and prolong the analgesic efficacy of the cocktail during both knee flexion and SLR activities on the second postoperative day.

Keywords: Anesthesia and analgesia; arthroplasty; knee; pain management; replacement.

\section{öz}

Amaç: $\mathrm{Bu}$ çalışmada eş zamanlı iki taraflı total diz artroplastisi sırasında lokal analjezik kokteylinin periartiküler enjeksiyonu (PAE) uygulanan hastalarda cilt altı lokal analjezik infüzyonunun (CaLAİ) ameliyat sonrası erken dönemdeki (özellikle ameliyat sonrası ikinci gün) analjezik ve fonksiyonel etkinliği değerlendirildi.

Hastalar ve yöntemler: Eş zamanlı iki taraflı total diz artroplastisi uygulanan ve ameliyat öncesi ve sirasında aynı analjezik protokolleri alan 15 hasta (1 erkek, 14 kadın; ort. yaş 62 yıl; dağılım 52-76 yıl) (30 diz) bu randomize, çift kör, plasebo kontrollü çalışmaya dahil edildi. Esnek bir kateter kullanılarak CaLAİ amaciyla dizlerden birine bupivakain (CaLAİ grubu) diğerine ise plasebo infüzyonu (kontrol grubu) uygulandı. Bupivakain ve plasebo infüzyonu yapılan dizler arasında ameliyat sonrası görsel ağrı ölçeği (GAÖ) skorları ve diz fonksiyonları karşılaştırıldı.

Bulgular: Ameliyat sonrası ikinci günde CaLAİ grubunda diz fleksiyonu ve düz bacak kaldırma (DBK) aktiviteleri sırasında GAÖ skorları kontrol grubundan daha düşüktü. CaLAİ aynı zamanda ameliyat sırasında yapılan lokal analjezik kokteylinin PAE sonrasında görülen tepki (rebound) ağrısı oluşumunu engelledi ve hem diz fleksiyonu hem de DBK sırasında kokteylin analjezik etkinlik süresini uzattı.

Sonuç: Cilt altı bupivakain infüzyonu, eş zamanlı iki taraflı total diz artroplastisi uygulanan hastalarda ameliyat sonrasi ikinci günde ameliyat sırasında uygulanan lokal analjezik kokteylinin PAE sonrasında görülen tepki ağrısının ortaya çıkmasını önleyebilir ve hem diz fleksiyonu hem de DBK aktiviteleri sırasında kokteylin analjezik etkinliğini uzatabilir.

Anahtar sözcükler: Anestezi ve analjezi; artroplasti; diz; ağrı yönetimi; replasman.

- Received: August 25, 2015 Accepted: October 16, 2015

- Correspondence: Mehmet Serhan Er, M.D. Akdeniz Üniversitesi Tıp Fakültesi Ortopedi ve Travmatoloji Anabilim Dalı, 07059 Kampus, Antalya, Turkey. Tel: +90 538 - 7459081 Fax: +90 242 - 2496040 e-mail: mserhan2005@hotmail.com 
Simultaneous bilateral total knee arthroplasty (SBTKA) is a major surgery associated with increased pain and delayed recovery in early postoperative period when compared with unilateral total knee arthroplasty (TKA). ${ }^{[1,2]}$ Total knee arthroplasty is a standard method of treatment for various disabling disorders of the knee and has proven long-term success.$^{[3]}$ Several methods to overcome postoperative pain after TKA (such as intrathecal morphine, epidural block, femoral or sciatic nerve blocks, periarticular multimodal drug injection [anesthetic cocktail], and intravenous opioids) are currently used. ${ }^{[2,4,5]}$ However, each method has its potential side effects.

Periarticular injection (PAI) with multimodal drugs in TKA provides targeting the origin of pain and minimizing side effects of the drugs and maximizing potential for immediate mobility and muscle control. ${ }^{[5]}$

Both administration of intraoperative $\mathrm{PAI}^{[6,7]}$ and postoperative continuous subcutaneous infusion with local anesthetics have been reported to be efficient in TKA ${ }^{[8]}$ However, the extent and duration of pain relieving effects of these pain control protocols vary between studies that encourage their use. ${ }^{[6,7,9]}$ Moreover, Lombardi et al. ${ }^{[6]}$ and Koh et al. ${ }^{[10]}$ observed a rebound effect with higher pain levels after applying PAI on postoperative days (PODs) one and two in the study group. To our knowledge, no study evaluated whether local analgesic administration to the subcutaneous tissue would overcome the rebound pain in the early postoperative period and prolong the analgesic effect of the intraoperative PAI.

In this study, we aimed to evaluate the analgesic and functional efficacy of subcutaneous local analgesic infusion (ScLAI) in the early postoperative period (especially on the second POD) in patients undergoing SBTKA with an intraoperative PAI of local analgesic cocktail.

\section{TABLE I}

Contents of analgesic cocktail and their amounts and doses

\begin{tabular}{lcc}
\hline Drug & Dose & Amount \\
\hline Bupivacaine 0.5\% $(\mathrm{mg})$ & 150 & 30 \\
Morphine sulphate $(\mathrm{mg})$ & 5 & 0.5 \\
Methylprednisolone acetate $(\mathrm{mg})$ & 40 & 1 \\
Cefuroxime $(\mathrm{mg})$ & 750 & 10 \\
Sodium chloride 0.9\% wt/vol $(\mathrm{mL})$ & 18.2 & 18.2 \\
Epinephrine 1/1000 $(\mu \mathrm{g})$ & 300 & 0.3 \\
\hline
\end{tabular}

\section{PATIENTS AND METHODS}

This prospective, double-blind, randomized and placebo-controlled study included 15 consecutive patients ( 1 male, 14 females; mean age 62 years; range 52 to 76 years) who underwent SBTKA. The study was conducted following approval by the Institutional Review Board. All patients provided their informed consents to participate in the study. The inclusion criteria included a diagnosis of primary osteoarthritis, a mental ability to provide informed consent, and to cooperate on the use of patient controlled analgesia (PCA) pump. The exclusion criteria included allergies to any of the drugs injected, acute or chronic knee infection, previous major bone surgery involving the knee joint, regular use of the narcotics, and low mental status to understand how to use the PCA pump.

All patients were operated under general anesthesia. The tourniquet was inflated just before incision and released after skin closure. The same surgeon using standard medial parapatellar approach performed all the TKAs sequentially. All patients received PAI of analgesic cocktail. The content and amounts of the analgesic cocktail are shown in Table I. A total of $60 \mathrm{~mL}$ cocktail was used for each knee. One third of the solution $(20 \mathrm{~mL})$ was injected into the posterior aspect of the capsule and medial and lateral collateral ligaments just prior to implantation of the components. After insertion of the prosthesis, $20 \mathrm{~mL}$ solution was infiltrated along quadriceps mechanism and the retinacular tissues. Another $20 \mathrm{~mL}$ was used to infiltrate the anterior subcutaneous tissues. A vacuum drain was placed into the knee joint and the capsule and extensor mechanism were repaired watertight. After joint closure, a multi-holed flat silicone catheter of a Jackson-Pratt ${ }^{\circledR}$ drain (Cardinal Health, Dublin, OH, USA) was placed subcutaneously

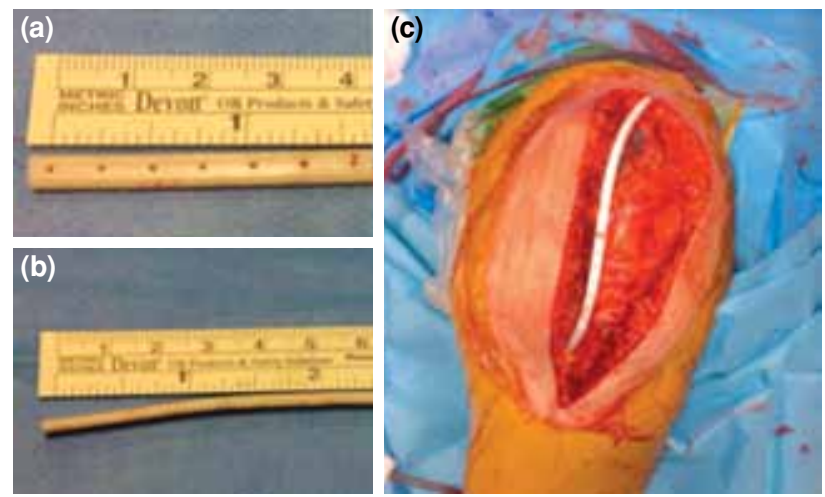

Figure 1. (a, b) Dimensions of Jackson-Pratt ${ }^{\circledR}$ drain. (c) Drain placed over watertight repaired capsule and extensor mechanism. 
TABLE II

Medications received by patients

\begin{tabular}{|c|c|c|c|}
\hline \multicolumn{4}{|l|}{ Routine medications } \\
\hline Diclofenac sodium & $75 \mathrm{mg}$ & $2 \times 1(0)$ & From morning of surgery to discharge \\
\hline Acetaminophen & $500 \mathrm{mg}$ & $4 \times 1(O)$ & From morning of surgery to discharge \\
\hline Cefazoline sodium & $2 \mathrm{~g}$ & $3 \times 1$ (IV) & $\begin{array}{l}\text { Thirty minutes before surgery, twice } \\
\text { postoperatively with eight hours of interval }\end{array}$ \\
\hline Low-molecular-weight heparin (Bemiparin sodium) & $3500 \mathrm{IU}$ & $1 \times 1(\mathrm{SC})$ & Daily for 15 days \\
\hline \multicolumn{4}{|l|}{ Postoperative pain medications } \\
\hline Morphine (IV PCA) & \multicolumn{2}{|c|}{$\begin{array}{l}\text { A bolus of } 1 \mathrm{mg} \text {, } \\
\text { a lock-out of six minutes, } \\
\text { and a maximum of } \\
10 \mathrm{mg} / \text { hour (IV) }\end{array}$} & For 24 hours after the surgery \\
\hline $\begin{array}{l}\text { Tramadol HCl } 37.5 \mathrm{mg}+\text { paracetamol } \\
325 \mathrm{mg}\left(\text { Zaldiar }^{\circledR}\right)\end{array}$ & \multicolumn{2}{|c|}{ Every 8 hours, (O) } & $\begin{array}{l}\text { When the postoperative VAS score at } \\
\text { rest was } \geq 3 \text {, }\end{array}$ \\
\hline Tramadol $\mathrm{HCl}\left(\right.$ Contramal $\left.^{\circledR}\right)$ & \multicolumn{2}{|c|}{$\begin{array}{c}100 \mathrm{mg} \text { in } 100 \mathrm{~mL} \\
0.9 \% \text { saline infusion } \\
\text { in } 30 \text { minutes (IV) }\end{array}$} & $\begin{array}{l}\text { When the postoperative VAS score } \\
\text { at rest was } \geq 7\end{array}$ \\
\hline
\end{tabular}

O: Oral; IV: Intravenous; SC: Subcutaneous; PCA: Patient controlled analgesia; VAS: Visual analog scale; HCl: Hydrochloride.

over the capsule (Figure 1a-c). The postoperative pain medications which the patients received are given in Table II.

The patients and surgeons were blinded to the infused solution to either knee and the anesthetist randomly conducted the infusions for both knees. Twenty-four hours after the operation, intravenous PCA was discontinued and continuous subcutaneous infusion of $40 \mathrm{~mL}$ bupivacaine $(5 \mathrm{mg} / \mathrm{mL})$ with $20 \mathrm{~mL} 0.9 \%$ saline in one knee (ScLAI group) and $60 \mathrm{~mL} 0.9 \%$ saline in the contralateral knee with a rate of $3 \mathrm{~mL} /$ hour (control group) were initiated by using PCA pump. The vacuum drain was removed on the second POD. Wounds were evaluated daily to determine whether any signs of skin ischemia or infection were present.

One of the authors recorded the primary outcome values -postoperative pain levels reported by the patient- with use of a visual analog scale (VAS) ranging from 0 to 10 . The assessments in the early postoperative period were conducted during resting and the activities of the knee [flexion and straight leg raise (SLR)] at the second, fourth, sixth, eighth, $10^{\text {th }}$, and $12^{\text {th }}$ hours after the operation; and hourly during 16 hours after starting subcutaneous infiltration through the catheter.

The secondary outcome variables involved functional recovery. Functional recovery of the knee was evaluated by monitoring the ability to perform active SLR and measuring active knee flexion with the patient in supine position and the extensor lag in sitting positions on PODs two, three, and six. Angular measurements were performed with a goniometer.

Data from a previous study on bilateral knee arthroplasty indicated that presence of 13 patients were required in each group to demonstrate a $20 \%$ difference in the pain score upon flexion of the knee four hours postoperatively, with a significance of 0.05 and a power of $0.80 .^{[8]}$ Thus, 15 patients were included in the study to compensate for inaccuracies.

\section{Statistical analysis}

SPSS version 15.0 software for Windows (SPSS Inc., Chicago, IL, USA) was used for the statistical analyses. The mean values and standard deviations were calculated for descriptive statistics of continuous variables and median values for discrete variables. The means of groups were analyzed by using student's t-test. Paired sample $t$ test was used to compare the mean values of the same variable which was measured at different time periods. Pearson's correlation coefficient was used to analyze whether significant correlation exists between the parameters. Two tailed hypothesis was considered in the analyses and statistical significance was defined as $p<0.05$.

\section{RESULTS}

The mean weight of the patients was $88.9 \mathrm{~kg}$ (range 70 to $120 \mathrm{~kg}$ ). There were no significant differences in the mean preoperative and early postoperative VAS scores at rest and during movement between 
TABLE III

Demographics of the patients and pain levels and functional results (degree of flexion, straight leg raise and degree of extension lag) of the groups

\begin{tabular}{|c|c|c|c|c|c|c|c|}
\hline & \multicolumn{3}{|c|}{ ScLAI } & \multicolumn{3}{|c|}{ Control } & \multirow[b]{2}{*}{$p$} \\
\hline & $\mathrm{n}$ & Mean & Range & $\mathrm{n}$ & Mean & Range & \\
\hline \multicolumn{8}{|l|}{ Number of patients $(n=15)$} \\
\hline Females & 14 & & & 14 & & & \\
\hline Male & 1 & & & 1 & & & \\
\hline \multicolumn{8}{|l|}{ Number of knees $(n=15)$} \\
\hline Right & 8 & & & 7 & & & \\
\hline Left & 7 & & & 8 & & & \\
\hline Mean age (years) & & 62.3 & $52-76$ & & 62.3 & $52-76$ & \\
\hline Mean weight (kg) & & 88.9 & $70-120$ & & 88.9 & $70-120$ & \\
\hline Mean operation time (minutes) & 119.6 & $90-180$ & & & 112 & $80-150$ & 0.410 \\
\hline Mean tourniquet time (minutes) & 88.7 & $59-127$ & & & 84.5 & $50-137$ & 0.573 \\
\hline Implant type & 10 CR- 5 PS & & & 10 CR- 5 PS & & & 1.000 \\
\hline Preoperative VAS rest & & 7.2 & & & 7.3 & & 0.842 \\
\hline EPOVAS rest & & 4.3 & & & 4.3 & & 0.976 \\
\hline Postoperative $2^{\text {nd }}$ day VAS rest & & 2.1 & & & 2.5 & & 0.084 \\
\hline Preoperative VAS flexion & & 7.9 & & & 8.0 & & 0.842 \\
\hline EPOVAS flexion & & 4.5 & & & 4.3 & & 0.876 \\
\hline Postoperative $2^{\text {nd }}$ day VAS flexion & & 3.2 & & & 3.5 & & $0.001^{*}$ \\
\hline Preoperative VAS SLR & & 7.6 & & & 7.9 & & 0.664 \\
\hline EPOVAS SLR & & 3.6 & & & 3.2 & & 0.401 \\
\hline Postoperative $2^{\text {nd }}$ day VAS SLR & & 3.1 & & & 4.0 & & $0.000^{*}$ \\
\hline Preoperative max. flexion $\left(^{\circ}\right)$ & & 116.3 & & & 119.3 & & 0.697 \\
\hline Postoperative $2^{\text {nd }}$ day max. flexion $\left(^{\circ}\right)$ & & 65.0 & & & 60.0 & & 0.632 \\
\hline Postoperative $3^{\text {rd }}$ day max. flexion $\left({ }^{\circ}\right)$ & & 76.3 & & & 75.7 & & 0.941 \\
\hline Postoperative $6^{\text {th }}$ day max. flexion $\left({ }^{\circ}\right)$ & & 104.0 & & & 104.3 & & 0.950 \\
\hline Preoperative extension Lag $\left(^{\circ}\right)$ & & 2.0 & & & 2.3 & & 0.754 \\
\hline Postoperative $2^{\text {nd }}$ day extension Lag $\left(^{\circ}\right)$ & & 5.7 & & & 5.0 & & 0.326 \\
\hline Postoperative $3^{\text {rd }}$ day extension Lag $\left(^{\circ}\right)$ & & 5.0 & & & 4.7 & & 0.667 \\
\hline Postoperative $6^{\text {th }}$ day extension Lag $\left(^{\circ}\right)$ & & 3.0 & & & 3.3 & & 0.749 \\
\hline
\end{tabular}

ScLAl: Subcutaneous infusion of local analgesics; CR: Cruciate retaining; PS: Posterior stabilized; VAS: Visual analog scale score; EPOVAS: Early postoperative mean visual analog scale score; SLR: Straight leg raise.

the ScLAI and control groups, as well as the range of motion, operation time, implant type, and tourniquet time (Table III).

The mean VAS scores during knee flexion and SLR in the second POD were statistically significantly different $(p<0.05)$ between the ScLAI and control groups (Figures 2, 3). A rebound pain was observed in the control group during knee flexion and SLR activities on the second POD (Table III).

There was a correlation between the duration of tourniquet use and VAS scores during the SLR activities at the second and fourth hours after the operation ( $\mathrm{p}=0.045, \mathrm{r}=0.642$ and $\mathrm{p}=0.037, \mathrm{r}=0.662$, respectively).

The ScLAI and control groups achieved similar ranges of active flexion in the first six PODs $\left(65^{\circ}\right.$ vs. $60^{\circ}$ on POD two; $76.3^{\circ}$ vs. $75.7^{\circ}$ on POD three; $104^{\circ}$ vs. $104.3^{\circ}$ on POD six). Furthermore, no significant differences were found in terms of SLR activities between the groups (Table III).

We observed no clinically detectable, serious drug related adverse effects such as cardiac and/or nervous system toxicity, or no superficial or deep infections.

\section{DISCUSSION}

This study demonstrated that ScLAI administered in patients undergoing SBTKA on the second day after surgery not only prevented the rebound pain during SLR activities but also prolonged the analgesic efficacy of the intraoperative PAI of local analgesic cocktail during both knee flexion and SLR activities. 


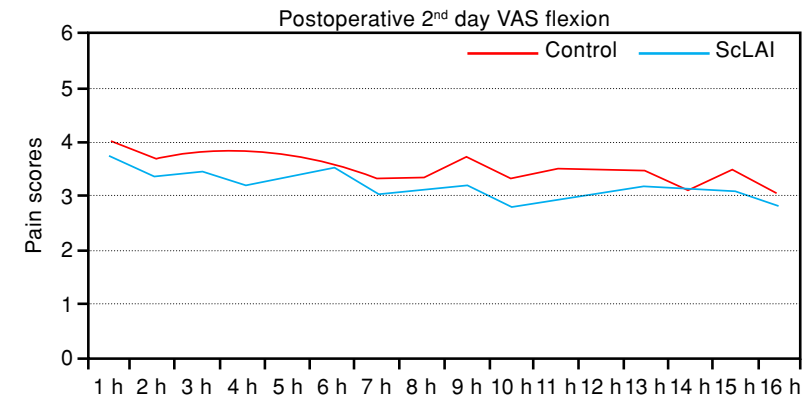

Figure 2. Mean visual analog pain scores for knees infiltrated with bupivacaine (ScLAl: Subcutaneous local analgesic infusion) or placebo during knee flexion on the second postoperative day. VAS: Visual analog scale.

Since pain thresholds vary between individuals, conclusions in studies conducted on different subjects may be confusing and conflicting. Evaluation of pain by the same subject may overcome this drawback. Unlike previous studies $[6,9,11-13]$ investigating the efficacy of intraoperative PAI in two different study groups, our study group included patients who blindly assessed pain levels between their knees and therefore served as an internal control as in studies of similar design in the literature. ${ }^{[8]}$

Another advantage of the current study is that the use of intravenous PCA was limited to 24 hours. Therefore, the pain and functional scores in both groups were evaluated without the masking effect of PCA. We believe that the total amount of opioid consumption may be neglected, because the same patient evaluated the pain levels between both knees.

This study has several limitations. First, although no superficial or deep infections were observed, the potential risk of infection while using a catheter should not be ignored. We placed the catheter subcutaneously to reduce the risk of deep infection as previously stated. ${ }^{[8]}$ Second, although it is wellknown that bupivacaine has cytotoxic, ${ }^{[14]}$ cardiotoxic and neurotoxic effects, ${ }^{[2]}$ plasma level of bupivacaine was not measured. However, no bupivacaine-induced side effects were observed in the present study. In various studies, the dose of bupivacaine used in cocktails differs. In this study, we used a total dose of $300 \mathrm{mg}$ bupivacaine, which is below the maximum safe total daily dose of $400 \mathrm{mg}{ }^{[15]}$ Third, although we did not record VAS scores of the patients after removal of the catheters, we did not receive any negative feedback in respect to pain from the patients after stopping the ScLAI. However, whether ScLAI postponed or completely prevented the rebound pain after intraoperative PAI of local analgesic cocktail can be questioned.

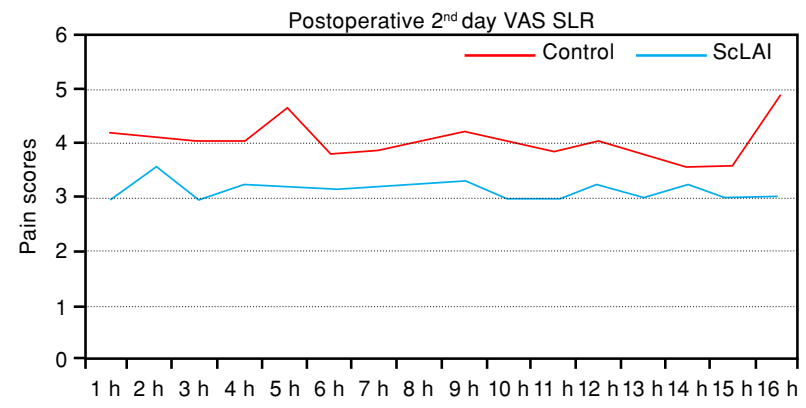

Figure 3. Mean visual analog pain scores for knees infiltrated with bupivacaine (ScLAl: Subcutaneous local analgesic infusion) or placebo during straight leg raise on the second postoperative day. VAS: Visual analog scale; SLR: Straight leg raise.

While the continuous ScLAI via a multi-holed catheter partly prolongs the analgesic effect of the intraoperative PAI that provides sufficient postoperative analgesia in the early postoperative period, future comparative trials using other methods or local analgesics need to incorporate well-defined methods to prolong the duration of analgesia.

\section{Conclusion}

Subcutaneous infusion of bupivacaine in patients undergoing SBTKA prevented emergence of the rebound pain after application of intraoperative PAI of local analgesic cocktail and prolonged the analgesic efficacy of the analgesic cocktail during both knee flexion and SLR activities on the second day after the surgery but did not change the final range of motion at the end of the sixth day.

\section{Declaration of conflicting interests}

The authors declared no conflicts of interest with respect to the authorship and/or publication of this article.

\section{Funding}

The authors received no financial support for the research and/or authorship of this article.

\section{REFERENCES}

1. Powell RS, Pulido P, Tuason MS, Colwell CW Jr, Ezzet KA. Bilateral vs unilateral total knee arthroplasty: a patientbased comparison of pain levels and recovery of ambulatory skills. J Arthroplasty 2006;21:642-9.

2. Sizlan A, Atım A, Yurttaş Y, Ozkan H, Bilge M, Kuyumcu $\mathrm{M}$, et al. A comparison of the efficacy of bupivacaine and levobupivacaine in patient-controlled epidural analgesia for postoperative pain in patients undergoing knee arthroplasty. [Article in Turkish] Eklem Hastalik Cerrahisi 2012;23:134-9.

3. Boya H, Özcan Ö, Maralcan G. An investigation of consistency between posterior condylar axis +3 degree external rotation line and clinical transepicondylar axis line techniques in primary total knee arthroplasty. 
Eklem Hastalik Cerrahisi 2014;25:70-4.

4. Andersen L $\varnothing$, Kehlet H. Analgesic efficacy of local infiltration analgesia in hip and knee arthroplasty: a systematic review. Br J Anaesth 2014;113:360-74.

5. Teng Y, Jiang J, Chen S, Zhao L, Cui Z, Khan MS, et al. Periarticular multimodal drug injection in total knee arthroplasty. Knee Surg Sports Traumatol Arthrosc 2014;22:1949-57.

6. Lombardi AV Jr, Berend KR, Mallory TH, Dodds KL, Adams JB. Soft tissue and intra-articular injection of bupivacaine, epinephrine, and morphine has a beneficial effect after total knee arthroplasty. Clin Orthop Relat Res 2004;428:125-30.

7. Jiang J, Teng Y, Fan Z, Khan MS, Cui Z, Xia Y. The efficacy of periarticular multimodal drug injection for postoperative pain management in total knee or hip arthroplasty. J Arthroplasty 2013;28:1882-7.

8. Andersen LØ, Husted H, Kristensen BB, Otte KS, GaarnLarsen L, Kehlet H. Analgesic efficacy of subcutaneous local anaesthetic wound infiltration in bilateral knee arthroplasty: a randomised, placebo-controlled, doubleblind trial. Acta Anaesthesiol Scand 2010;54:543-8.

9. Busch CA, Shore BJ, Bhandari R, Ganapathy S, MacDonald SJ, Bourne RB, et al. Efficacy of periarticular multimodal drug injection in total knee arthroplasty. A randomized trial. J Bone Joint Surg [Am] 2006;88:959-63.

10. Koh IJ, Kang YG, Chang CB, Do SH, Seong SC, Kim TK. Does periarticular injection have additional pain relieving effects during contemporary multimodal pain control protocols for TKA?: A randomised, controlled study. Knee 2012;19:253-9.

11. Vendittoli PA, Makinen P, Drolet P, Lavigne M, Fallaha M, Guertin MC, et al. A multimodal analgesia protocol for total knee arthroplasty. A randomized, controlled study. J Bone Joint Surg [Am] 2006;88:282-9.

12. Fu P, Wu Y, Wu H, Li X, Qian Q, Zhu Y. Efficacy of intra-articular cocktail analgesic injection in total knee arthroplasty - a randomized controlled trial. Knee 2009;16:280-4.

13. Lamplot JD, Wagner ER, Manning DW. Multimodal pain management in total knee arthroplasty: a prospective randomized controlled trial. J Arthroplasty 2014;29:329-34.

14. Güngör İ, Yilmaz A, Ergün MA, Öztürk AM, Kaya K. Does hyaluronic acid decrease the apoptotic effect of bupivacaine? Eklem Hastalik Cerrahisi 2014;25:102-6.

15. De Jong R. Local anesthetic pharmacology. In: Brown DL, editor. Regional Anesthesia and Analgesia. Philadelphia: W.B. Saunders; 1996. p. 124-42. 